Vol. 23, No. 1 (Mei 2020) $01-38$

e-ISSN: 2614-0071 || p-ISSN: 1410-9328

\title{
Saksi Pidana Pembunuhan Dalam Kitab Undang-Undang Hukum Pidana Dengan Hukum Islam
}

\author{
Besse Muqita Rijal Mentari \\ Sekolah Tinggi Ilmu Hukum, Lamaddukelleng Sengkang \\ ${ }^{\Omega}$ Surel Koresponden: muqitadewimentari_trmdm@yahoo.com
}

\begin{abstract}
:
Studi komparasi sebagai metode penelitian terhadap artikel sanksi pidana pembunuhan dalam Kitab Undang-Undang Hukum Pidana dengan Hukum Islam. Penelitian dilaksanakan di Wilayah Kabupaten Wajo dengan menggunakan Metode pengumpulan data yang digunakan adalah wawancara serta Observasi sedangkan Sampel yang dipergunakan adalah dengan menggunakan Purposive sampling, kemudian Data dianalisis secara Normatif, dimana bertujuan untuk Mengetahui "Bagaimana sanksi pidana pembunuhan menurut KUHP Berdasarkan latar belakang masalah diatas, maka permasalahan yang akan dikaji dalam penelitian ini adalah: "Bagaimana sanksi pidana pembunuhan menurut hukum Islam. Hasil penelitian menunjukkan bahwa Tindak pidana pembunuhan ialah kejahatan yang dilakukan berupa penyerangan terhadap nyawa orang lain. Tindak pidana pembunuhan yang dilakukan dengan sengaja dalam KUHP diatur dalam Buku Kedua Bab XIX Pasal 338 sampai dengan Pasal 350 mengenai Kejahatan Terhadap Nyawa. Sedangkan pada tindak pidana pembunuhan yang tidak sengaja diatur dalam Buku Kedua Bab XXI KUHP Pasal 359. Hukum Islam membagi tindak pidana pembunuhan menjadi tiga macam, yaitu pembunuhan yang dilakukan dengan sengaja, pembunuhan yang dilakukan tidak dengan sengaja dan pembunuhan yang dilakukan menyerupai sengaja. Landasan hukum mengenai tindak pidana pembunuhan ini diatur dalam beberapa ayat dalam Al Quran dan juga diatur dalam Hadist Nabi Muhammad SAW. Hukum pidana Indonesia maupun hukum pidana Islam menguraikan unsur kesengajaan adalah berupa perbuatan yang dikehendaki pelakunya akan menimbulkan suatu akibat tertentu. Dalam hal tindak pidana pembunuhan yang disengaja, akibat yang dikehendaki oleh pelaku adalah meninggalnya orang lain. Sedangkan pada pembunuhan yang tidak disengaja pelaku tidakmenghendaki akibat yang akan terjadi. Oleh sebab itu dalam KUHP maupun hukum Islam sanksi pidana pembunuhan yang disengaja akan lebih berat daripada yang tidak disengaja. Sanksi pidana pembunuhan yang diatur dalam KUHP dapat berupa pidana mati, pidana penjara, pidana kurungan dan pidana tambahan. Sedangkan dalam hukum pidana Islam sanksi pidana pembunuhan dapat berupa hukuman qishash, hukuman diyat, kifarat, dan hukuman ta'zir. Hukum pidana Indonesia merupakan mutlak hukum publik (hukum Negara), yaitu hukum yang mengatur hubungan antara orang/perseorangan (warga negara) dengan Negara.
\end{abstract}

Keywords: sanksi; pemidanaan; sistem hukum;

\begin{abstract}
Abstrak:
Comparative study as a research method for articles of criminal sanctions for murder in the Criminal Law Act with Islamic Law. The study was conducted in the Wajo Regency using data collection methods used were interviews and observations while the sample used was using purposive sampling, then the data were analyzed normatively, which aims to find out "How criminal
\end{abstract}


sanctions for murder according to the Criminal Code Based on the background of the above problems, then the problem to be examined in this study is: "What about criminal sanctions for murder according to Islamic law. The results showed that the crime of murder is a crime committed in the form of an attack on the lives of others. The criminal acts of murder committed intentionally in the Criminal Code are regulated in the Second Book of Chapter XIX Article 338 to Article 350 concerning Crimes Against Life. Whereas the murder crime which is unintentionally regulated in the Second Book of Chapter XXI of the Criminal Code Article 359. Islamic law divides the crime of murder into three types, namely murder committed intentionally, murder committed unintentionally and the murder committed resembles intentionally. The legal basis for the crime of murder is regulated in several verses in the Koran and also in the Hadith of the Prophet Muhammad. Indonesian criminal law and Islamic criminal law outline the element of intent is in the form of an act that the desired culprit will have a certain effect. In the case of an intentional murder crime, the desired result by the perpetrator is the death of another person. Whereas in unintentional killings the perpetrators do not want the consequences that will occur. Therefore both in the Criminal Code and Islamic law, the sanctions of intentional murder will be more severe than those unintentional. Penalties for murder which are regulated in the Criminal Code can be in the form of capital punishment, imprisonment, confinement and additional penalties. Whereas in Islamic criminal law sanctions for murder can be in the form of qishash, diyat, kifarat, and ta'zir penalties. Indonesian criminal law is public law (state law), which is the law that governs the relationship between individuals / individuals (citizens) and the State.

Keywords: sanction; crime; murder;

Submit : 01-02-2020

Accepted : 02-04-2020

Doi: https://doi.org/10.56087/aijih.v23i1.33

\section{PENDAHULUAN}

Sistem hukum Indonesia sebagai sebuah sistem aturan yang berlaku di negara Indonesia adalah sistem aturan yang sangat luas dan komplek, yang terdiri dari unsur-unsur hukum, diantara unsur hukum yang satu dengan yang lain saling berhubungan, saling mempengaruhi dan saling mengisi. Oleh karenanya membicarakan satu bidang atau subsistem hukum yang berlaku di Indonesia tidak dapat dipisahkan satu dengan yang lain, unsur hukum seperti satu organ yang tidak bisa dipisahkan dari organ yang lain.

Indonesia adalah negara hukum. Sebagai negara hukum tentu harus memiliki hukum nasional sendiri, dimaksudkan sebagai pedoman untuk melaksanakan roda pemerintahan. dalam membentuk hukum nasional bangsa Indonesia mengambil dari tiga sistem hukum. Tiga sistem hukum dimaksud adalah hukum adat, hukum Islam dan hukum eks-Barat. Setiap negara tentu memiliki sistem hukum yang berbedabeda. Salah satu bidang hukum itu adalah hukum pidana. 
Hukum pidana ialah hukum yang mengatur tentang pelanggaran-pelanggaran dan kejahatan-kejahatan terhadap kepentingan umum, perbuatan mana diancam dengan hukuman yang merupakan suatu penderitaan atau siksaan. Dalam hukum pidana Indonesia, kita mengenal adanya Kitab Undang-Undang Hukum Pidana (Wetboek van Strafrecht) atau yang sering disebut dengan KUHP, merupakan pokok dari peraturan perundang-undangan yang mengatur tentang hukum pidana yang berupa "pelanggaran dan kejahatan" terhadap norma-norma hukum mengenai kepentingan umum yang berlaku di Indonesia. KUHP memuat peraturan-peraturanpidana yang berlaku terhadap segenap penduduk dari seluruh Indonesia, karena ia dibuat oleh Badan Legislatif yang tertinggi dan sesuai dengan asas unifikasi hukum. ${ }^{1}$

Selain hukum pidana, di Indonesia terdapat hukum yang berlaku secara formal, yaitu hukum adat dan hukum Islam. Namun hukum Islam yang berlaku di Indonesia umumnya hanya mengatur tentang hal hal yang bersifat kekeluargaan atau yang mengatur tentang hubungan antar individu, misalnya masalah perkawinan dan kewarisan, ini pun hanya berlaku bagi warga Negara Indonesia yang beragama Islam.

Di Indonesia, hukum Islam tidak mengatur mengenai hukum pidana Islam atau yang disebut dengan jinayah atau jarimah, sebab segala sesuatu mengenai hukum pidana yang ada di Indonesia diatur dalam peraturan perundang-undangan yang dibuat oleh Badan Legislatif. Hukum Islam (fiqih) sebagai salah satu sistem hukum yang berlaku di Indonesia telah mendapatkan tempatnya dengan jelas ketika mantan Menteri Kehakiman Ali Said berpidato di depan simposium Pembaharuan Hukum Perdata Nasional yang diadakan pada tanggal 21 Desember 1981 di Yogyakarta. Mengenai kedudukan hukum Islam dalam pembinaan hukum nasional, bahwa hukum Islam yang merupakan salah satu komponen tata hukum Indonesia menjadi salah satu sumber bahan baku bagi pembentukan hukum nasional. Dengan demikian jelas hukum Islam tidak dapat dipisahkan dari kehidupan mayoritas masyarakat Indonesia.

Pada hakekatnya, hukum Islam mencakup berbagai aspek kehidupanumat manusia, baik yang mengatur mengenai ibadah maupun muamalah. dalam bidang Ibadah,

${ }^{1}$ C.S.T.Kansil. 1989. Pengantar Ilmu Hukum dan Tata Hukum Indonesia. Jakarta : Balai Pustaka. hal 23 
hukum Islam mengatur mengenai hubungan manusia dengan Allah SWT. Sedangkan dalam bidang muamalah, Islam mengajarkan bagaimana adab dalam hidup bergaul dengan masyarakat atau mengenai halhal yang berhubungan dengan masalah keduniawian. Selain itu, dalam hukum Islam juga mengatur tentang macam-macam perbuatan yang dilarang menurut syara' (syari'at) atau yang disebut dengan jinayat. Adapun perbuatan yang termasuk dalam jinayat antara lain, mencuri, berzina, minum-minuman keras, murtad, pembunuhan, dan masih ada beberapa perbuatan lain yang dilarang oleh syara'. Dari beberapa contoh jinayat diatas, salah satu perbuatan yang paling dilarang atau dilaknat oleh Allah SWT ialah membunuh atau menghilangkan nyawa seseorang. Sebagaimana firman Allah SWT dalam Al-Quran Surat An-Nisa' Ayat 93.

Dalil tersebut menegaskan bahwa balasan terhadap orang yang melakukan pembunuhan adalah siksaan yang teramat pedih di akhirat dan di kutuk oleh Allah SWT. Pembunuhan dapat menghancurkan tata nilai hidup yang telah dibangun oleh kehendak Allah SWT, dan merampas hak hidup orang yang menjadi korban. Para ulama pun mendefinisikan pembunuhan dengan suatu perbuatan manusia yang menyebabkan hilangnya nyawa. Pembunuhan juga merupakan perbuatan yang kejam, sebab juga berdampak terhadap orang lain yang ditinggalkannya (korban). Pembunuhan menyebabkan anak-anak menjadi yatim, istri menjadi janda dan keluarga korban juga merasa kehilangan. "Sebagian fuqaha membagi pembunuhan menjadi dua bagian, yaitu pembunuhan sengaja dan pembunuhan kesalahan. Pembunuhan sengaja ialah suatu perbuatan dengan maksud menganiaya dan menyebabkan hilangnya nyawa orang yang dianiaya. Sedangkan pembunuhan kesalahan ialah suatu perbuatan yang menyebabkan kematian yang tidak disertai niat penganiayaan".2

Begitupula dalam hukum pidana Indonesia, pembunuhan atau merampas nyawa orang lain juga merupakan salah satu perbuatan pidana dengan sanksi yang sangat berat. Dalam KUHP tindak pidana pembunuhan salah satunya dikenal dengan pembunuhan yang tidak disengaja (culpose misdrijven). Selain itu terdapat pembunuhan yang disengaja atau direncanakan (dolus misdrijven). Pada

\footnotetext{
${ }^{2}$ H.A. Djazuli. 2000. Fiqh Jinayah. Jakarta : Raja Grafindo Persada. hal, 41
} 
pembunuhan yang direncanakan terlebih dahulu, ancaman hukumannya lebih berat daripada yang tidak direncanakan terlebuh dahulu.

Pada kedua bidang ilmu hukum tersebut, masing-masing mempunyai aturan yang berbeda dalam hal sanksi atau hukuman terhadap pelaku tindak pidana pembunuhan. Dalam hukum pidana Indonesia, pengaturannya bersumber pada Kitab Undang-Undang Hukum Pidana (KUHP), sedangkan dalam hukum Islam pengaturannya berdasarkan pada Al-Qur'an dan al Hadist. Berdasarkan uraian diatas, maka artikel ini akan mengkaji dan meneliti lebih dalam mengenai sanksi tindak pidana pembunuhan yang diatur dalam KUHP dan yang diatur menurut Hukum Islam (syariat Islam). Adapun rumusan masalah yang secara kongkrit dijawab dalam pembahasan, yaitu: Bagaimana sanksi pidana pembunuhan menurut KUHP, sanksi pidana pembunuhan menurut hukum Islam.

\section{METODE}

Lokasi Penelitian ini dilakukan di wilaya kabupaten Wajo dengan pertimbangan bahwa objek permasalahan yang dibahas bertempat di Kabupaten Wajo, Jenis Penelitian ini merupakan jenis penelitian hukum normatif atau penelitian hukum doktrinal, karena hukum dikonsepkan sebagai peraturan perundang-undangan. Peraturan perundang-undangan disini adalah Al-Quran, hadist, dan Kitab UndangUndang Hukum Pidana (KUHP). Sifat Penelitian ini adalah deskriptif, yaitu suatu penelitian yang mempunyai tujuan untuk memaparkan atau menggambarkan secara lengkap dan sistematis objek yang diteliti, yaitu tentang sanksi pidana pembunuhan yang diatur dalam KUHP dan hukum Islam. Pendekatan penelitian nilai ilmiah suatu pembahasan dan pemecahan masalah terhadap legal issue yang diteliti sangat tergantung kepada cara pendekatan (approach) yang digunakan". ${ }^{3}$ Penelitian ini menggunakan pendekatan perbandingan (comparative approach). Pendekatan perbandingan merupakan salah satu cara yang digunakan dalam penelitian normative untuk membandingkan salah satu lembaga hukum dari sistem hukum yang satu dengan sistem hukum yang lain, dan dari perbandingan tersebut dapat

${ }^{3}$ Johnny Ibrahim. 2006. Teori \& Metodelogi Penelitian Hukum Normatif. Malang : Bayumedia., hal, 299 
ditemukan unsur-unsur persamaan dan perbedaaan kedua sistem hukum tersebut. Dalam hal ini ialah sistem hukum pidana (KUHP ) dan hukum Islam.

Jenis Data yang digunakan dalam penelitian ini adalah data sekunder, yaitu data yang tidak diperoleh langsung dari sumbernya, tetapi diperoleh dari bahan pustaka, antara lain buku-buku, literatur, peraturan perundang-undangan, hasil penelitian terdahulu, artikel, internet dan sumber lain yang berkaitan dengan penelitian ini. Sumber Data yang digunakan dalam penelitian normatif adalah sumber data sekunder, yaitu data yang bersumber dari bahan-bahan kepustakaan, berupa dokumen, buku, laporan, arsip, dan literatur-literatur yang berkaitan dengan masalah yang diteliti. Sumber data sekunder yang akan digunakan dalam penelitian ini adalah sebagai berikut :Bahan hukum primer dalam penelitian ini antara lain : Al Qur'an, Hadist Rasulullah SWT dan Kitab Undang-Undang Hukum Pidana (KUHP).dan Bahan Hukum Sekunder Bahan hukum sekunder sebagai pendukung dari data sekunder bahan hukum primer yang akan digunakan dalam penelitian ini yaitu terdiri atas : buku- buku teks yang ditulis oleh ahli hukum, dokumen resmi, karya ilmiah, artikel, dan internet. Bahan Hukum Tersier adalah bahan hukum yang memberikan petunjuk maupun penjelasan terhadap bahan hukum primer dan bahan hukum sekunder, yaitu kamus maupun ensiklopedia.

Teknik Pengumpulan Data yang digunakan dalam penelitian ini adalah studi kepustakaan, yaitu pengumpulan data sekunder dari peraturan perundang undangan, buku-buku, dokumen, artikel, dan pengumpulan data yang diambil melalui internet, yang digunakan sebagai data penunjang dalam penulisan penelitian hukum. Teknik Analisis Data Pada penelitian hukum normatif, teknik analisis data yang digunakan adalah non statistik. Analisis data adalah proses mengorganisasikan dan mengurutkan data ke dalam pola, kategori, dan satuan uraian dasar, sehingga dapat ditentukan tema dan dapat dirumuskan menjadi hipotesis kerja seperti yang terdapat di dalam data. ${ }^{4}$ Teknik analisis data dalam penelitian penting agar data-data yang sudah terkumpul, kemudian dianalisis agar dapat menghasilkan jawaban yang dapat dipertanggungjawabkan dari permasalahan. Teknis analisis data yang dipergunakan peneliti dalam penelitian ini adalah teknik analisis data yang bersifat content analysis, yaitu teknik analisis data dengan cara mengkaji isi suatu data

${ }^{4}$ Lexy J. Moelong. 2002. Metodologi Penelitian Kualitatif. Bandung: Remaja Rosdakarya. hal, 103 
sekunder yang sudah dikumpulkan agar disusun, kemudian dijelaskan dari materi perundangundangan.

\section{HASIL}

\section{A. Sanksi Pidana Pembunuhan menurut Kitab Undang-Undang Hukum Pidana (KUHP)}

Tindak pidana pembunuhan atau kejahatan terhadap nyawa dalam KUHP secara garis besar dikelompokkan menjadi 2(dua) golongan, yaitu pertama berdasarkan unsur kesalahannya, kedua berdasarkan objeknya. Berdasarkan unsur kesalahannya tindak pidana pembunuhan dibedakan menjadi 2(dua) macam, yaitu:

(1) Kejahatan terhadap nyawa yang dilakukan dengan sengaja (dolus misdrijven). Kejahatan ini diatur dalam Buku Kedua Bab XIX KUHP Pasal 338 sampai dengan Pasal 350.

(2) Kejahatan terhadap nyawa yang dilakukan dengan tidak sengaja (culpose misdrijven). Tindak pidana ini diatur dalam Buku Kedua Bab XXI KUHP Pasal 359.

Berdasarkan objeknya/korban (kepentingan hukum yang dilindungi) kejahatan terhadap nyawa dibedakan menjadi 3(macam), yaitu:

(1) Kejahatan terhadap nyawa manusia pada umumnya, diatur pada Pasal 338, 339, 340, 344, dan 345 KUHP.

(2) Kejahatan terhadap nyawa bayi pada saat dilahirkan atau sesaat/tidak lama setelah dilahirkan, perbuatan ini diatur dalam Pasal 341, 342, dan 343 KUHP.

(3) Kejahatan terhadap nyawa bayi yang masih ada dalam kandungan atau masih berupa janin, dimuat dalam Pasal 346, 347, 348, dan 349 KUHP. Pada penelitian ini penulis mengkategorikan tindak pidana pembunuhan atau kejahatan terhadap nyawa menjadi 2(dua) macam, yaitu kejahatan terhadap nyawa yang dilakukan dengan sengaja dan yang dilakukan tidak dengan sengaja. 
1. Tindak Pidana Pembunuhan yang Dilakukan dengan Sengaja

Kitab Undang-Undang Hukum Pidana (KUHP) mengatur mengenai tindak pidana pembunuhan yang dilakukan dengan sengaja terdiri dari 7(tujuh) macam, yaitu sebagai berikut :

a. Pembunuhan dalam Bentuk Biasa

Delik ini diatur dalam Pasal 338 KUHP yang merumuskan bahwa : "barangsiapa sengaja merampas nyawa orang lain, diancam, karena pembunuhan, dengan pidana penjara paling lama lima belas tahun." Pada pembunuhan biasa ini, pelaksanaannya haruslah tidak lama setelah timbulnya kehendak (niat) dari pelaku untuk menghilangkan nyawa korban. Sebab apabila terdapat tenggang waktu yang cukup lama dari timbulnya kehendak untuk membunuh dengan pelaksanaannya, maka pembunuhan tersebut termasuk dalam pembunuhan berencana. Pada pembunuhan biasa ini, Pasal 338 KUHP menyatakan bahwa pemberian sanksi atau hukuman pidananya adalah pidana penjara paling lama lima belas tahun. Disini disebutkan bahwa "paling lama", jadi tidak menutup kemungkinan hakim akan memberikan sanksi pidana pidana kurang dari lima belas tahun penjara.

b. Pembunuhan yang Diikuti, Disertai atau Didahului dengan Tindak Pidana Lain

Delik ini diatur dalam pasal 339 KUHP, yang rumusannya sebagai berikut: "Pembunuhan yang diikuti, disertai atau didahului oleh sesuatu perbuatan pidana yang dilakukan dengan maksud untuk mempersiap atau mempermudah pelaksanaannya, atau melepaskan diri sendiri maupun peserta lainnya dari pidana dalam hal tertangkap tangan, ataupun untuk memastikan penguasaan barang yang diperolehnya secara melawan hukum, diancam dengan pidana penjara seumur hidup atau selama waktu tertentu, paling lama dua puluh tahun" Pada pembunuhan dalam Pasal 339 KUHP merupakan suatu bentuk khusus pembunuhan yang diperberat. Dalam pembunuhan yang diperberat ini terdapat 2(dua) macam 
tindak pidana sekaligus, yaitu pembunuhan biasa dan tindak pidana lain. Adanya unsur diikuti, disertai atau didahului oleh tindak pidana lain artinya tindak pidana lain ini harus sudah terjadi, tidak boleh baru percobaan, sebab apabila pembunuhannya sudah terjadi namun tindak pidana lainnya belum terjadi maka delik tersebut belum termasuk dalam Pasal 339 KUHP ini. Oleh karena terdapat 2(dua) tindak pidana, yaitu pembunuhan dan tindak pidana selain pembunuhan, maka orang yang dipertangungjawabkan adalah orang yang melaksanakan pembunuhan tersebut, sedangkan bagi orang lain yang tidak terlibat secara objektif, maka ia hanya bertanggungjawab atas tindak pidana lain yang dilakukannya saja. Pada kasus pembunuhan yang diatur dalam Pasal 339 KUHP ini, ancaman pidananya adalah pidana penjara seumur hidup atau selama waktu tertentu, paling lama dua puluh tahun. Sanksi pidana pada pembunuhan ini termasuk relatif berat dibandingkan dengan pembunuhan biasa yang diatur dalam Pasal 338 KUHP, karena dalam perbuatan ini terdapat dua delik sekaligus.

\section{c. Pembunuhan Berencana}

Tindak pidana ini diatur dalam Pasal 340 KUHP, yang menyebutkan sebagai berikut: "Barangsiapa sengaja dan dengan rencana lebih dahulu merampas nyawa orang lain, diancam, karena pembunuhan dengan rencana (moord), dengan pidana mati atau pidana penjara seumur hidup atau selama waktu tertentu, paling lama dua puluh tahun." Pembunuhan berencana ini mencakup pada pembunuhan biasa atau yang diatur dalam Pasal 338 KUHP ditambah dengan adanya unsur perencanaan terlebih dahulu. Ancaman pidana pada pembunuhan berencana ini lebih berat daripada pembunuhan yang ada pada Pasal 338 dan 339 KUHP bahkan merupakan pembunuhan dengan ancaman pidana yang paling berat, yaitu pidana mati, dimana sanksi pidana mati ini tidak tertera pada kejahatan terhadap nyawa lainnya, yang menjadi dasar beratnya hukuman ini 
adalah pada adanya perencanaan terlebih dahulu tersebut. Selain diancam dengan pidana mati, pelaku tindak pidana pembunuhan berencana juga dapat dipidana penjara seumur hidup atau selama waktu tertentu paling lama dua puluh tahun.

d. Pembunuhan oleh Ibu terhadap Bayinya

Tindak pidana pembunuhan terhadap bayi ini dibagi menjadi 2(dua) macam, yaitu : Pertama, pembunuhan bayi yang dilakukan dengan tidak berencana (pembunuhan bayi biasa). Kedua, pembunuhan bayi yang dilakukan dengan perencanaan terlebih dahulu.

(1) Pembunuhan bayi yang dilakukan dengan tidak berencana (pembunuhan bayi biasa) Pembunuhan ini diatur dalam Pasal 341 KUHP, rumusannya adalah sebagai berikut : "Seorang ibu yang, karena takut akan ketahuan melahirkan anak, pada saat anak dilahirkan atau tidak lama kemudian, dengan sengaja merampas nyawa anaknya, diancam, karena membunuh anak sendiri, dengan pidana penjara paling lama tujuh tahun"

(2) Pada kasus pembunuhan ini KUHP memberikan ancaman hukuman bagi pelakunya dengan pidana penjara paling lama tujuh tahun. Sanksi pidana pembunuhan ini jauh lebih ringan dibandingkan dengan pembunuhan biasa. Penulis berpendapat bahwa lebih ringannya sanksi pidana tersebut karena dilihat dari subjek atau pelaku pembunuhannya. Pada saat melakukan pembunuhan, pelaku sedang mengalami kondisi kejiwaan yang labil atau sedang dalam keadaan tertekan batinnya karena adanya perasaan takut diketahui orang lain. Sehingga kondisi kejiwaan yang demikian dinilai sebagai mengurangi kesalahan pelaku (ibu) atas tindak pidana pembunuhan yang telah dilakukan terhadap bayinya. Namun hal tersebut tidak dapat dijadikan 
sebagai alasan yang sah untuk menghapuskan sifat melawan hukumnya perbuatan ibu membunuh bayinya.

(3) Pembunuhan bayi yang dilakukan dengan perencanaan terlebih dahulu Pembunuhan ini diatur dalam Pasal 342 KUHP, yangrumusannya adalah sebagai berikut: "Seorang ibu yang untuk melaksanakan niat yang ditentukan karena takut akan ketahuan bahwa akan melahirkan anak, pada saat anak dilahirkan atau tidak lama kemudian merampas nyawa anaknya, diancam, karena melakukan pembunuhan anak sendiri dengan rencana, dengan pidana penjara paling lama Sembilan tahun"

Munculnya kehendak untuk membunuh ini haruslah pada saat sebelum bayi tersebut dilahirkan. Ini merupakan syarat utama untuk dapat dikualifikasikan sebagai pembunuhan bayi berencana. Apabila kehendak itu muncul pada saat bayi dilahirkan, maka pembunuhan tersebut termasuk pada pembunuhan bayi Pasal 341 KUHP.

Ancaman sanksi pidana pada pembunuhan berencana ini relatif lebih berat dibandingkan dengan pembunuhan biasa pada bayi (Pasal 341 KUHP). Hal ini didasarkan pada adanya perencanaan terlebih dahulu sebelum melakukan pembunuhan. Dalam KUHP disebutkan bahwa ancaman sanksi pidana terhadap ibu yang membunuh bayinya sendiri pada saat atau tidak lama setelah dilahirkan yang didahului dengan perencanaan adalah dengan pidana penjara paling lama sembilan tahun. Sama halnya dengan pembunuhan berencana (Pasal 340 KUHP) dimana ancaman pidananya juga lebih berat daripada pembunuhan biasa (Pasal 338 KUHP). Kaitannya dengan Pasal 341 dan 342 KUHP, dalam KUHP juga diatur mengenai orang lain yang turut serta melakukan tindak pidana pembunuhan terhadap bayi. Hal ini diatur dalam Pasal 343 KUHP, yang menyatakan bahwa : "Kejahatan yang diterangkan dalam Pasal 341 dan 342 dipandang, bagi orang lain yang turut serta melakukan, sebagai pembunuhan atau pembunuhan dengan 
rencana" Artinya bahwa orang lain yang turut serta dalam pembunuhan bayi tidak dapat diberlakukan ketentuan seperti pada Pasal 341 dan 342 KUHP, namun ia diberlakukan terhadap pelanggaran pada pembunuhan biasa (Pasal 338 KUHP) atau pembunuhan berencana (Pasal 340 KUHP). Jadi sanksi pidana terhadap orang lain yang turut melakukan pembunuhan tersebut adalah diberlakukan sama dengan pembunuhan biasa (Pasal 338 KUHP) atau pembunuhan berencana (Pasal 340 KUHP). Tujuan dari ketentuan Pasal 343 KUHP ini adalah supaya orang lain yang turut melakukan tersebut tidak mendapatkan keringanan hukuman sebagaimana yang telah didapatkan oleh pelaku (ibu bayi), sebab sudah barang tentu latar belakang dari pembunuhan ini berbeda. Apabila pelakunya adalah ibu, dia membunuh bayinya karena adanya tekanan jiwa (takut), namun pada orang lain motifnya mungkin lain, bukan karena takut.

\section{e. Pembunuhan atas Permintaan Korban Sendiri}

Pembunuhan ini diatur dalam Pasal 344 KUHP yang rumusannya adalah sebagai berikut: "Barangsiapa merampas nyawa orang lain atas permintaan orang itu sendiri yang jelas dinyatakan dengan kesungguhan hati, diancam dengan pidana penjara paling lama dua belas tahun" Pembunuhan yang diatur dalam Pasal 344 KUHP ini berbeda dengan pembunuhan biasa yang diatur dalam Pasal 338 KUHP. Perbedaannya ialah pada pembunuhan ini :

(1) Dilakukan atas permintaan korban sendiri

(2) Secara jelas dinyatakan dengan kesungguhan hati.

Apabila kedua unsur diatas tidak terbukti atau tidak ada, maka pembunuhan tersebut akan masuk dalam pembunuhan biasa. Semua syarat diatas bersifat kumulatif, artinya bahwa semua syarat tersebut harus dipenuhi untuk dapat dikualifikasikan sebagai tindak pidana pembunuhan yang melanggar Pasal 344 KUHP. Menurut Pasal 344 KUHP, ancaman pidana pada pembunuhan atas permintaan korban sendiri adalah pidana penjara paling lama dua 
belas tahun. Hukuman ini relatif lebih ringan daripada pembunuhan biasa (Pasal 338 KUHP), mengingat bahwa inisiatif dari pembunuhan ini dari permintaan korban itu sendiri, bukan dari pelaku. Sehingga pelaku sedikit mendapatkan keringanan ancaman pidananya.

f. Penganjuran dan Pertolongan pada Bunuh Diri

Tindak pidana ini diatur di dalam Pasal 345 KUHP, yang rumusannya adalah sebagai berikut: "Barangsiapa sengaja mendorong orang lain untuk bunuh diri, menolongnya dalam perbuatan itu atau memberi sarana kepadanya untuk itu, diancam dengan pidana penjara paling lama empat tahun kalau orang itu jadi bunuh diri." Pada kejahatan terhadap nyawa yang diatur dalam Pasal 345 KUHP ini, pelakunya diancam dengan pidana penjara paling lama empat tahun. Sanksi pidana ini termasuk yang paling ringan diantara sanksi pidana kejahatan terhadap nyawa pada umumnya lainnya. Hal ini didasarkan pada subjek/pelaku tindak pidananya tidak secara langsung melakukan pembunuhan, melainkan korban sendirilah yang membunuh dirinya sendiri. Pelaku hanya sebagai pendorong, menolong, atau memberi sarana dalam perbuatan bunuh diri. Berbeda dengan pembunuhan biasa atau pembunuhan berencana dimana yang melakukan pembunuhan terhadap korban adalah pelakunya sendiri.

g. Pengguguran dan Pembunuhan terhadap Kandungan Tindak pidana pengguguran terhadap janin ini berdasarkan subjeknya dibagi menjadi 2(dua) macam, yaitu:

a) Dilakukan sendiri.

b) Dilakukan oleh orang lain, juga dibagi menjadi 2(dua) macam, yaitu :

(1) Atas persetujuan wanita yang mengandung janin.

(2) Tanpa persetujuan wanita yang mengandung janin. 
Pada kejahatan terhadap nyawa ini, diatur dalam empat pasal, yaitu Pasal 346, 347, 348, dan 349 KUHP. Masing-masing akan diuraikan sebagai berikut:

- Pengguguran dan pembunuhan terhadap janin yang dilakukannya sendiri Tindak pidana ini diatur dalam Pasal 346 KUHP, yang isinya sebagai berikut.

"seorang wanita yang sengaja menggugurkan atau mematikan kandungnnya atau menyuruh orang lain untuk itu, diancam dengan pidana penjara paling lama empat tahun" Adapun inisiatif dari dilakukannya kejahatan ini adalah dari wanita yang mengandung janin itu sendiri, bukan orang lain. Oleh karena itu wanita tersebut telah menghendaki perbuatannya dan mengetahui akibat dari perbuatannya itu berupa gugur/matinya janin yang ada dikandungannya. Terhadap wanita yang melakukan tindak pidana ini, KUHP memberikan ancaman sanksi pidana berupa pidana penjara paling lama empat tahun. Ancaman sanksi pidana pada kejahatan ini juga relatif ringan dibandingkan dengan kejahatan terhadap nyawa lainnya.

- Pengguguran dan pembunuhan terhadap kandungan tanpa persetujuan wanita yang mengandung Kejahatan terhadap nyawa ini diatur dalam Pasal 347 KUHP yang menyatakan sebagai berikut:

(1) Barangsiapa dengan sengaja menggugurkan atau mematikan kandungan seorang wanita tanpa persetujuannya, diancam dengan pidana penjara paling lama dua belas tahun

(2) Jika perbuatan itu mengakibatkan matinya wanita tersebut, dikenakan pidana penjara paling lama lima belas tahun" Maksud dari "tanpa persetujuannya" adalah wanita tersebut tidak menghendaki akibat perbuatan tersebut yang berupa gugurnya atau matinya kandungan yang ada di rahimnya. Contoh kasus 
misalnya seorang wanita yang sedang hamil diancam oleh orang lain (pacarnya) untuk menggugurkan kandungannya dengan cara meminumkan jamu/obat penggugur kehamilan, karena adanya ancaman kekerasan akhirnya wanita tersebut menggugurkan kandungannya. Pada contoh kasus ini yang dapat dipidana adalah laki-laki (pacarnya) tersebut, sedangkan terhadap wanitanya tidak dapat dipidana karena dia dalam keadaan terpaksa atau adanya daya paksa (overmacht), sebagaimana diatur dalam Pasal 48 KUHP yang menyatakan bahwa "barangsiapa melakukan perbuatan karena pengaruh daya paksa, tidak dipidana" Tindak pidana yang berupa pengguguran dan pembunuhan terhadap kandungan tanpa persetujuan wanita yang mengandung ini dalam Pasal 347 KUHP ancaman hukumannya adalah yang paling berat diantara kejahatan terhadap kandungan lainnya, yaitu dalam ayat (1) disebutkan bahwa ancaman pidananya adalah pidana penjara paling lama dua belas tahun. Bahkan dalam ayat (2) disebutkan apabila perbuatannya itu menyebabkan meninggalnya wanita tersebut, pelaku diancam dengan pidana penjara paling lama lima belas tahun.

c) Pengguguran dan pembunuhan kandungan dengan persetujan wanita yang mengandung. Kejahatan ini diatur dalam Pasal 348 KUHP, yang isinya sebagai berikut : “ Barangsiapa dengan sengaja menggugurkan atau mematikan kandungan seorang wanita dengan persetujuannya, diancam dengan pidana penjara paling lama lima tahun enam bulan (2) Jika perbuatan itu mengakibatkan matinya wanita tersebut, dikenakan pidana penjara paling lama tujuh tahun." Oleh karena adanya persetujuan dari wanita yang mengandung inilah sehingga ancaman pidananya juga jauh lebih ringan daripada tanpa adanya persetujuan (Pasal 347 KUHP). Dalam ayat (1) Pasal 348 disebutkan bahwa ancaman pidana terhadap pelaku adalah pidana penjara paling lama lima tahun enam bulan, sedangkan 
pada ayat (2) disebutkan bahwa apabila perbuatannya tersebut mengakibatkan matinya wanita itu, dikenakan pidana penjara paling lama tujuh tahun.

d) Pengguguran atau pembunuhan kandungan oleh tabib/dokter, bidan, atau juru obat. Pada kejahatan terhadap kandungan ini diatur dalam ketentuan Pasal 349 KUHP, yang rumusannya adalah sebagai berikut: "Jika seorang tabib, bidan, atau juru obat membantu melakukan kejahatan yang tersebut Pasal 346, ataupun melakukan atau membantu melakukan salah satu kejahatan yang diterangkan dalam Pasal 347 dan 348, maka pidana yang ditentukan dalam pasal itu dapat ditambah dengan sepertiga dan dapat dicabut hak untuk menjalankan pencarian dalam mana kejahatan dilakukan."

Pada ketentuan pasal diatas, disebutkan bahwa yang bertindak sebagai subjek/pelaku adalah tabib/dokter, bidan, atau juru obat. Perbuatan ini dapat berupa secara langsung mauapun hanya membantu melakukan. Ancaman bagi pelaku kejahatan ini lebih berat daripada pelaku kejahatan yang ada dalam Pasal 347 maupun 348 KUHP, yaitu pidananya dapat ditambah dengan sepertiganya, meskipun sekedar sebagai pembantu saja. Selain itu, pelaku juga dapat dipidana dengan dicabutnya haknya untuk melakukan pencahariaannya itu. Misalnya seorang dokter atau bidan dapatdicabut ijin prakteknya. Tentu hal ini tidak sesuai dengan ketentuan Pasal 57 KUHP tentang Pembantuan, dimana dalam Pasal 57 ancaman pidana bagi Pembantu kejahatan justru dikurangi sepertiganya.

Bagi pelaku tindak pidana pembunuhan, selain diancam dengan pidana pokok berupa penjara, juga dapat diberikan sanksi pidana tambahan, sebagaimana diatur dalam Pasal 350 KUHP, yang menyatakan sebagai berikut: "Dalam pemidanaan karena pembunuhan, karena pembunuhan dengan rencana, atau karena salah satu kejahatan yang diterangkan dalam Pasal 344, 347, dan 
348, dapat dijatuhkan pencabutan hak tersebut Pasal 35 nomor 15."

2. Tindak Pidana Pembunuhan yang Dilakukan Tidak dengan Sengaja Tindak pidana pembunuhan yang dilakukan dengan tidak sengaja merupakan bentuk kejahatan yang akibatnya tidak dikehendaki oleh pelaku. Kejahatan ini diatur dalam Pasal 359 KUHP, yang rumusannya sebagai berikut : Barangsiapa karena kealpaannya menyebabkan matinya orang lain, diancam dengan pidana penjara paling lama lima tahun atau kurungan paling lama satu tahun"

Letak perbedaan bentuk kejahatan pembunuhan terhadap nyawa orang lain antara Pasal 338 dan 359 KUHP ini adalah pada Pasal 338 terdapat unsur kesengajaan dan sedangkan pada Pasal 359 adanya unsur kealpaan. Terhadap kejahatan yang melanggar Pasal 359 KUHP ini, ada dua macam hukuman yang dapat dijatuhkan terhadap pelakunya yaitu berupa pidana penjara paling lama lima tahun atau pidana kurungan paling lama satu tahun.

Sehingga bentuk sanksi hukuman ini juga merupakan unsur yang membedakan bentuk pembunuhan yang disengaja dengan yang tidak disengaja. Sebab dalam pembunuhan yang disengaja tidak ada sanksi pidana kurungan, semuanya berupa pidana penjara. Adapun yang mendasari perbedaan ini adalah pada unsur kesengajaan. Pada pembunuhan yang tidak disengaja, pelaku tidak menghendaki timbulnya akibat yang berupa kematian pada orang lain, sedangkan pada pembunuhan yang disengaja pelaku menghendaki akibat yang akan terjadi

\section{B. Tinjauan dan Penerapan Sanksi Pidana Pembunuhan menurut Hukum Islam}

1. Pembunuhan yang Dilakukan dengan Sengaja ('Amad)

Imam Nawawi merumuskan bahwa kesengajaan ialah perbuatan seseorang terhadap orang lain dengan apa-apa yang biasanya dapat membunuh, baik 
yang melukai maupun mutsaqqol (memberatkan). Jadi unsurnya ada 3(tiga) macam, yaitu: 5
a) Perbuatan itu dikehendaki
b) Akibat perbuatan itu dikehendaki oleh si pelaku
c) Dengan alat yang biasanya membunuh.

Adapun mengenai sanksi pidana pembunuhan yang disengaja dan terencana dalam hukum Islam, pihak wali dari terbunuh diberi dua alternatif hukuman yang akan dijatuhkan terhadap pelaku yang telah membunuh ahli waris atau keluarganya, yaitu :

1) Menuntut hukum qishas

2) Memaafkan dengan mendapat imbalan diyat.

Pembunuhan dengan sengaja ini diatur dalam Al Quran Surat Al Baqarah ayat 178, yang artinya: "Hai orang-orang yang beriman, diwajibkan atas kamu qishash berkenaan dengan orang-orang yang dibunuh; orang merdeka dengan orang merdeka, hamba dengan hamba, dan wanita dengan wanita. Maka barangsiapa yang mendapat suatu pemaafan dari saudaranya, hendaklah (yang memaafkan) mengikuti dengan cara yang baik, dan hendaklah (yang diberi maaf) membayar (diyat) kepada yang memberi maaf dengan cara yang baik (pula). Yang demikian itu adalah suatu keringanan dari Tuhan. kamu dan suatu rahmat. Barangsiapa yang melampaui batas sesudah itu, Maka baginya siksa yang sangat pedih"

Berdasarkan ayat diatas disebutkan Allah telah mewajibkan hukum qishas dan pembalasan yang setimpal dalam pelaksanaannya, yakni orang merdeka dihukum mati karena telah membunuh orang merdeka, bukan karena membunuh budak, dan budak dihukum mati karena membunuh budak lainnya, wanita dihukum mati karena telah membunuh wanita. Namun apabila wali dari korban memaafkan, maka terhadap pelakunya diwajibkan untuk membayar diyat. Diyat ini sebagai pengganti dari hukuman qishas.

${ }^{5}$ Marsum. 2008. Jinayat (Hukum Pidana Islam). Yogyakarta : Universitas Islam Indonesia Press, hal, 102 
Al Quran Surat Al Israa' Ayat 33 Allah berfirman , yang artinya : “Dan janganlah kamu membunuh jiwa yang diharamkan Allah (membunuhnya), melainkan dengan suatu (alasan) yang benar. Dan barangsiapa dibunuh secara zalim, maka sesungguhnya Kami telah memberi kekuasaaan kepada ahli warisnya, tetapi janganlah ahli waris itu melampaui batas dalam membunuh. Sesungguhnya ia adalah orang yang medapatkan pertolongan". Ahli waris dari korban tidak boleh menuntut balas atau hukuman melebihi batas yang telah ditentukan oleh Allah, misalnya ahli waris sudah menuntut qishas kepada korban namun juga masih menuntut pembayaran diyat. Inilah yang dilarang oleh Allah karena telah melampaui batas, sebab diyat merupakan pengganti qishas. Hukum qishas tidak boleh dilaksanakan, kecuali telah memenuhi beberapa syarat berikut ini:

a. Si pembunuh haruslah orang mukallaf (aqil baligh), sehingga anak kecil, orang gila, dan orang yang tidur tidak terkena hukum qishas. Rasulullah SAW bersabda, yang artinya :"Diangkat pena dari tiga golongan: (Pertama) dari anak kecil hingga baligh, (kedua) dari orang tidak waras pikirannya hingga sadar (sehat), dan (ketiga) dari orang yang tidur hingga terjaga" (H.R. Ahmad, Abu Daud, dan Tirmidzi). 2) Orang yang terbunuh adalah orang yang terlindungi darahnya, yaitu bukan orang yang darahnya terancam dengan salah satu sebab yang disebutkan dalam hadist Nabi saw, yang artinya : "Tidak halal darah seorang muslim kecuali dengan satu di antara tiga..." (H.R. Abu Dawud dan Nasa'i).

b. Hendaknya si terbunuh bukanlah anak si pembunuh, karena ada Hadist Nabi Muhammad SAW, yang artinya : Umar Ibnu al-Khaththab Radliyallaahu 'anhu berkata: Aku mendengar Rasulullah Shallallaahu 'alaihi wa Sallam bersabda: "Seorang ayah tidak dituntut karena membunuh anaknya" (H.R. Ahmad, Tirmidzi, dan Ibnu Majah).

c. Hendaknya si korban bukanlah orang kafir, sedangkan si pembunuh orang muslim. Nabi Muhammad SAW bersabda, yang artinya : "Orang muslim tidak boleh dibunuh karena telah (membunuh) orang kafir" (H.R. Tirmidzi dan Nasa'i). Mengenai besarnya diyat, dijelaskan dalam Hadist Rasulullah SAW, yang artinya : "Barangsiapa yang membunuh 
(orang tak bersalah) secara sengaja (dan terencana), maka urusannya kepada pihak keluarga si terbunuh. Jika mereka mau, menuntut hukum balas membunuh; dan jika mau, mereka menuntut diyat, yaitu (membayar) tiga puluh hiqqah (onta betina berusia tiga tahun yang masuk tahun keempat) dan tiga puluh jadza'ah (onta yang masuk tahun kelima) serta empat puluh khalifah (onta yang sedang bunting) dan, apa saja yang mereka tuntut kepada si pembunuh sebagai imbalan perdamaian, maka ia (imbalan itu) untuk mereka, dan yang demikian itu untuk penekanan pada diyat" (H.R. Tirmidzi dan Ibnu Majah).

Abu Hanifah berpendapat bahwa pembunuhan yang disengaja jika dimaafkan oleh keluarganya, tidak dituntut pembayaran diyat yang telah ditentukan besarnya melainkan tergantung dari persetujuan dari keluarga korban dengan pelaku, dan apa yang telah disepakati oleh kedua belah pihak harus dibayar tunai dari harta si pembunuh itu sendiri. Pendapat Abu Hanifah ini didasarkan atas tidak disebutkannya dengan jelas berapa besar penggantian diyat dalam Al-Quran. ${ }^{6}$ Apabila pelaku pembunuhannya lebih dari seorang atau sekelompok orang maka mereka semua akan terkena hukum qishas.

Dasarnya ialah apa yang diriwayatkan oleh Imam Maliki dalam kitabnya Al muwaththa, yang artinya : "dari Sa'id bin Musayyab bahwa Umar bin Khathab ra pernah membunuh sekelompok orang, yaitu lima atau tujuh orang karena telah membunuh seorang laki-laki dengan pembunuhan secara tipu daya (yaitu membujuk korban hingga mau keluar ke tempat yang sepi lalu dibunuh), dan dia berkata, 'Andaikata penduduk negeri Shan'a bersekongkol membunuhnya, niscaya kubunuh mereka semuanya” Dalam Hadist juga dijelaskan, Rasulullah SAW bersabda, yang artinya : "Seandainya penduduk langit dan penduduk bumi semuanya bersekutu dalam mengalirkan darah seorang mukmin, niscaya Allah akan menjerumuskan mereka semuanya kedalam neraka" (H.R. Tirmidzi). Berdasarkan kedua dalil diatas disebutkan bahwa barang siapa yang membantu dalam suatu pembunuhan seorang

${ }^{6}$ Ahmad Azhar Basyir. 2006. Ikhtisar Fikih Jinayat (Hukum Pidana Islam). Yogyakarta : Universitas Islam Indonesia Press. hal, 21 
mukmin tanpa alasan yang dibenarkan, maka hukumannya sama dengan pembunuhan dalam hukum qishas di dunia dan siksaan di akhirat kelak. Hukuman qishas maupun diyat bisa tidak dijatuhkan atau dibebasakan terhadap pelaku apabila pihak wali telah memafkan pelaku terhadap perbuatan yang telah dilakukannya secara cuma-cuma.

Memaafkan secara cuma-cuma tanpa menuntut apa-apa kepada si pembunuh adalah sikap yang paling utama lagi mulia. Allah SWT berfirman dalam Al Quran Surat Al Baqarah Ayat 237, yang artinya : "Dan pemaafan kamu itu lebih dekat kepada takwa" Dalam Hadist juga disebutkan bahwa Rasulullah SAW bersabda, yang artinya: "Dan, Allah tidak menambah pada seorang karena pemaafannya, melainkan kemuliaan" (H.R. Tirmidzi dan Muslim). Jadi barangsiapa (wali) yang memaafkan pelaku pembunuhan atas perbuatan yang telah dilakuan terhadap ahli warisnya tanpa menuntut pembayaran diyat (pemaafan cuma-cuma), mereka akan lebih dekat dengan ketakwaan mendapatkan kemuliaan disisi Allah.

\section{Pembunuhan yang Dilakukan dengan Serupa Sengaja (Syabah 'Amad)}

Pengertian dari pembunuhan yang menyerupai sengaja ialah suatu perbuatan yang pada umumnya dilakukan dengan sesuatu yang biasanya tidak menyebabkan kematian. Misalnya dengan kerikil, tongkat, memukul dengan tangan kosong. Terdapat 3(tiga) unsur dalam pembunuhan yang menyerupai sengaja ini, yaitu :

a) Adanya perbuatan yang mengakibatkan kematian

b) Adanya maksud untuk penganiayaan

c) Ada hubungan sebab akibat antara perbuatan pelaku dengan kematian Imam Nawawi memberikan rumusan pembunuhan serupa sengaja ialah pemukulan dengan apa yang biasanya tidak membunuh.

Seandainya pukulan tersebut hanya menggunakan kayu ringan dan hanya dipukulkan satu atau dua kali saja lalu orang tersebut meninggal, maka ini dapat disebut sebagai pembunuhan serupa sengaja. Dasar hukum pembunuhan yang menyerupai sengaja ini adalah Ad-Daruquthni meriwayatkan sebuah hadist dari Ibnu Abbas, bahwa Nabi SAW pernah 
bersabda, yang artinya :"Kesengajaaan (mengharuskan) hukuman qishas, dan kesalahan hanya bayar diat tanpa qishas. Barang siapa dibunuh diluar kesengajaan dengan batu atau tongkat, atau cemeti, maka (si pembunuh) wajib atasnya diyat yang diberatkan dalam bentuk onta yang sudah cukup umur" Imam Ahmad, Abu Daud dan An Nasa'I meriwayatkan sebuah hadist bahwa Nabi Muhammad SAW pernah berkhotbah sewaktu penaklukan kota Mekah, disitu Beliau bersabda, yang artinya : "Ingatlah, sesungguhnya orangorang yang terbunuh secara menyerupai kesengajaan adalah (yang dibunuh) memakai cemeti, tongkat, dan batu"

Berdasarkan dalil-dalil diatas disebutkan bahwa pada dasarnya pembunuha serupa sengaja hampir sama dengan pembunuhan sengaja. Bedanya adalah pada pembunuhan sengaja menggunakan alat yang tidak selazimnya dapat mengakibatkan kematian atau untuk membunuh. Misalnya dengan cemeti, tongkat atau batu. Ketiga alat tersebut pada umumnya tidak dapat digunakan sebagai alat untuk membunuh. Oleh sebab itu dinamai sebagai pembunuhan serupa sengaja, bukan pembunuhan sengaja sepenuhnya atau bukan pembunuhan kesalahan secara mutlak. Ancaman sanksi pidana pembunuhan serupa sengaja ini adalah diyat mughallazhah yaitu diyat yang diperberat.

Diyat ini seperti pada pembunuhan sengaja karena mengingat perbuatann bukanlah merupakan suatu kesalahan yang murni, sebab pemukulannya itulah yang menjadi tujuan dari perbuatannya, bukan pada meninggalnya korban atau untuk membunuh korban. Akan tetapi terhadap pelaku pembunuhan menyerupai sengaja tidak boleh dituntut hukuman qishas. Imam Ahmad meriwayatkan dari Abu Daud dari 'Amr Ibn Syu'aib, bahwa Rasulullah bersabda, yanga artinya : "Diyat membunuh serupa sengaja diberatkan sama dengan membunuh sengaja, akan tetapi pelakunya tidak dihukum mati. Demikian itu supaya setan menyingkir dari kalangan manusia, sehingga peristiwa pembunuhan tersebut dapat diselesaikan dengan kepala dingin tanpa dendam atau mengangkat senjata" Adapun dasar bahwa diyat sebagai hukuman pokok adalah dari hadist yang menyebutkan bahwa, yang artinya : "Ketahuilah bahwa pada pembunuhan sengaja yang tersalah yaitu pembunuhan dengan cambuk, tongkat, dan batu wajib diyat seratus ekor onta" 
Menurut Imam Syafi'i dan Imam Ahmad waktu pembayaran diyat pada pembunuhan serupa sengaja adalah dalam jangka waktu tiga tahun sejak meninggalnya korban. Sedangkan menurut Imam Abu Hanifah adalah mulai dijatuhkannya vonis atas pembunuh. ${ }^{7}$

3. Pembunuhan yang dilakukan dengan Tidak Sengaja (Khata')

Pembunuhan yang tidak disengaja adalah seorang mukallaf melakukan perbuatan yang mubah baginya, seperti memanah binatang buruan, ternyata anak panahnya nyasar mengenai orang hingga meninggal dunia. Seperti pada hukum pidana Indonesia, pada pembunuhan yang tidak disengaja ini pelakunya tidak menghendaki timbulnya akibat yang akan terjadi. Unsur pembunuhan kesalahan (tidak sengaja) ada 3(tiga) macam, yaitu:

(a.) Adanya perbuatan yang menyebabkan kematian

(b.) Terjadinya perbuatan itu karena kesalahan

(c.) Adanya hubungan sebab-akibat antara perbuatan kesalahan dengan kematian.

Kesalahan ialah apabila sesuatu terjadi bukan karena kehendak orang yang melakukan perbuatan itu. Pada umumnya kesalahan itu terjadi karena kealpaan, kurang hati-hati, kecerobohan, dan sebagainya. Ketentuan mengenai hal ini dijelaskan dalam firman Allah SWT dalam Al Quran Surat An Nisa' Ayat 92, yang artinya : “Dan tidak layak bagi seorang mukmin membunuh seorang mukmin (yang lain), kecuali karena tersalah (tidak sengaja), dan barangsiapa membunuh seorang mukmin karena tersalah (hendaklah) ia memerdekakan seorang hamba sahaya yang beriman serta membayar diyat yang diserahkan kepada keluarganya (si terbunuh itu), kecuali jika mereka (keluarga terbunuh) bersedekah. Jika ia (si terbunuh) dari kaum yang memusuhimu, padahal ia mukmin, maka (hendaklah si pembunuh) memerdekakan hamba sahaya yang mukmin. Dan jika ia (si terbunuh) dari kaum (kafir) yang ada perjanjian (damai) antara mereka dengan kamu, Maka (hendaklah si pembunuh) membayar diyat yang diserahkan kepada keluarganya (si terbunuh) serta memerdekakan hamba sahaya yang beriman.

${ }^{7}$ H.A. Djazuli. 2000. Fiqh Jinayah. Jakarta : Raja Grafindo Persada. hal, 146 
Barangsiapa yang tidak memperolehnya, Maka hendaklah ia (si pembunuh) berpuasa dua bulan berturut-turut untuk penerimaan Taubat dari pada Allah. dan adalah Allah Maha mengetahui lagi Maha Bijaksana". Ada tiga macam bentuk pembunuhan yang tidak disengaja berdasarkan objek/korbannya, yaitu :

1) Membunuh orang mukmin

2) Membunuh orang yang memusuhi orang Islam, padahal ia mukmin

3) Membunuh orang kafir yang ada perjanjian (damai) dengan orang Islam.

Pada pembunuhan yang tidak sengaja terhadap orang mukmin ini, pelaku diberikan sanksi hukuman berupa membayar kifarat yaitu memerdekakan seorang hamba sahaya yang beriman serta membayar diyat yang diserahkan kepada keluarganya (wali). Namun keluarga korban juga boleh bersedekah, maksudnya adalah membebaskan pelaku pembunuhan dari pembayaran diyat atau memaafkan secara cuma-cuma. Seorang mukmin yang membunuh kaum yang memusuhinya padahal dia (korban) juga seorang mukmin karena kesalahan atau tidak sengaja hanya diwajibkan membayar kifarat berupa memerdekakan hamba sahaya yang beriman. Pada pembunuhan ini pelaku tidak diwajibkan membayar diyat kepada keluarga korban.

Seorang mukmin yang membunuh orang kafir yang mempunyai perjanjian damai kaum muslim dengan tidak sengaja dikenai hukuman diyat yang dibayarkan kepada keluarga korban serta wajib membayar kifarat berupa memerdekakan hamba sahaya yang beriman Dalam ayat diatas disebutkan bahwa "Barangsiapa yang tidak memperolehnya, Maka hendaklah ia (si pembunuh) berpuasa dua bulan berturut-turut" maksudnya adalah apabila si pembunuh tidak dapat memenuhi kewajibannya yaitu membayar diyat dan memerdekakan hamba sahaya yang beriman, maka ia diwajibkan untuk menggantinya dengan cara berpuasa selama dua bulan berturut-turut tanpa terputus.

\section{Penerapan Sanksi Pidana}

Tindak pidana pembunuhan dalam KUHP disebut juga sebagai kejahatan terhadap nyawa. Kejahatan terhadap nyawa ialah kejahatan yang dilakukan berupa 
penyerangan terhadap nyawa orang lain. Objek dari kejahatan ini adalah nyawa manusia. Jadi dalam hal ini suatu perbuatan dapat disebut sebagai tindak pidana pembunuhan apabila korbannya adalah manusia, bukan hewan atau sejenisnya. Dalam perbuatan menghilangkan nyawa orang lain terdapat 3(tiga) syarat yang harus dipenuhi, yaitu: ${ }^{8}$

a. Adanya wujud perbuatan

b. Adanya suatu kematian (orang lain)

c. Adanya hubungan sebab dan akibat (causal verband) antara perbuatan dan akibat kematian.

Pembunuhan atau kejahatan terhadap nyawa merupakan delik materiil, yaitu suatu tindak pidana yang melarang timbulnya akibat tertentu. Jadi yang dipandang dari delik materiil adalah timbulnya akibat dari perbuatan tersebut dan pada selesainya perbuatan itu, bukan pada bagaimana cara yang dilakukannya (dibacok, ditembak, dipukul). Misalnya ditembak ternyata tidak mengakibatkan matinya korban, maka ini belum termasuk pada delik pembunuhan, namun masih berupa percobaan pembunuhan. Timbulnya akibat dari hilangnya nyawa tidaklah harus seketika atau sesaat setelah perbuatan terjadi, namun dapat timbul beberapa waktu kemudian, yang penting akibatnya benar-benar disebabkan karena perbuatan tersebut. Misalnya pada kasus penembakan, karena korban menderita luka berat, setelah seminggu kemudia ia meninggal, maka hal ini dapat disebut sebagai pembunuhan yang disebabkan karena penembakan. Persoalan hubungan sebab-akibat (kausalitas) ini terdapat beberapa teori atau ajaran-ajaran kausalitas, antara lain sebagai berikut:

a) Teori ekivalensi menyatakan bahwa setiap syarat adalah sebab, dan semua syarat nilainya sama, jika salah satu syarat tidak ada, maka akibatnya akan berbeda. Contoh, A dianiaya oleh B, kemudian di bawa ke rumah sakit, dijalan A tertabrak motor, lalu meninggal, maka penganiayaan yang dilakukan oleh B ini juga merupakan sebab dari matinya A. Kelemahan dari teori ini adalah hubungan kausalnya membentang kebelakang tanpa akhir, karena setiap "sebab" merupakan "akibat" dari "sebab" yang terjadi sebelumnya. Kelebihan

\footnotetext{
${ }^{8}$ Adami Chazawi. 2001. Kejahatan Terhadap Tubuh \& Nyawa. Jakarta : Raja Grafindo Persada. hal, 57
} 
dari teori ini adalah mudah diterapkan, karena teori ini menarik secara sangat luas dalam berlakunya pertanggungjawaban pidana.

b) Teori individualisasi menentukan faktor "sebab" hanya melihat faktor mana yang paling berperan atau yang paling menentukan terhadap timbulnya "akibat".

c) Teori generalisasi menentukan faktor "sebab" melihat pada factor mana yang pada umumnya menurut kewajaran atau menurut perhitungan yang layak dapat menimbulkan "akibat". Tindak pidana pembunuhan dalam hukum Islam terdapat perbedaan pendapat diantara para ulama dalam mengkategorikannya. Imam Malik hanya menetapkan dua macam pembunuhan yaitu pembunuhan yang disengaja dan pembunuhan yang tidak disengaja, hal ini disebabkan karena Al Quran hanya menyebutkan dua macam pembunuhan, yaitu sengaja dan tidak sengaja.

Pembunuhan semi sengaja hanya disebutkan dalam Hadist. Namun Hadist yang menyebutkan adanya pembunuhan semi sengaja itu dinilai lemah karena riwayatnya mudhtharib. ${ }^{9}$ Pada pembahasan ini akan dibandingkan mengenai sanksi pidana pembunuhan yang disengaja dan pembunuhan yang tidak disengaja yang diatur dalam KUHP dan berdasarkan hukum Islam.

1. Pembunuhan yang Disengaja

Pengertian dari pembunuhan dengan sengaja dalam hukum Islam ialah seorang mukalaf secara sengaja dan terencana membunuh orang yang terlindungi darahnya (tak bersalah), dengan dasar kehendak yang kuat bahwa dia harus dibunuh olehnya. Kata sengaja berasal dari kata "amida" atau "amad". Dalam Al Quran menggunakan kata "muta'ami" yang artinya dengan sengaja. Pengertian dari pembunuhan yang disengaja ini mirip dengan yang diatur dalam hukum pidana Indonesia yaitu pelaku menghendaki akibat yang akan terjadi dari perbuatan yang dilakukannya, yaitu meninggalnya orang lain. Dalam KUHP, pembunuhan yang disengaja diatur pada Pasal 338 sampai dengan Pasal 350. Pada umumnya sanksi pidana terhadap pembunuhan yang disengaja yang diatur pada KUHP adalah

${ }_{9}^{9}$ Ahmad Azhar Basyir. 2006. Ikhtisar Fikih Jinayat (Hukum Pidana Islam). Yogyakarta : Universitas Islam Indonesia Press, hal, 33 
berupa pidana penjara selama waktu tertentu yang lamanya tergantung pada subjek/pelaku, objek/korban, bentuknya, dan ada atau tidak adanya perencanaan terlebih dahulu. Pembunuhan yang disengaja dalam hukum Islam diatur dalam Al Quran Surat Al Baqarah ayat 178, yang artinya : "Hai orang-orang yang beriman, diwajibkan atas kamu qishash berkenaan dengan orang-orang yang dibunuh; orang merdeka dengan orang merdeka, hamba dengan hamba, dan wanita dengan wanita. Maka barangsiapa yang mendapat suatu pemaafan dari saudaranya, hendaklah (yang memaafkan) mengikuti dengan cara yang baik, dan hendaklah (yang diberi maaf) membayar (diyat) kepada yang memberi maaf dengan cara yang baik (pula). Yang demikian itu adalah suatu keringanan dari Tuhan kamu dan suatu rahmat. Barangsiapa yang melampaui batas sesudah itu, Maka baginya siksa yang sangat pedih."

Pada ayat diatas disebutkan bahwa pidana qishas ditetapkan atas dasar persamaan antara pelaku dan korban. Orang merdeka di-qishas karena membunuh orang merdeka; budak di-qishas karena membunuh budak; wanita di-qishas karena membunuh wanita; Namun para fukaha berselisih pendapat mengenai syarat persamaan tersebut. Dengan memperhatikan ajaran Islam tentang hak hidup bagi umat manusia, maka pembunuhan dengan sengaja secara umum dapat mengakibatkan hukuman qishas.

Hukum pidana Islam memberikan sanksi pidana pembunuhan yang disengaja berupa hukuman qishas, yaitu hukuman yang sama dengan perbuatan yang telah dilakukannya, oleh karena perbuatannya berupa pembunuhan, maka pelaku juga akan mendapatkan sanksi pidana pembalasan berupa dibunuh atau dihukum mati. Namun dalam hukum pidana Islam dikenal adanya pemaafan atas perbuatan yang dilakukan oleh pelaku dari keluarga korban. Pemaafan ini dapat meringankan hukuman terhadap pelaku, dimana yang seharusnya pelaku mendapatkan sanksi hukuman qishas, namun karena adanya pemaafan dari keluarga korban maka pelaku dapat dibebaskan dari hukuman qishas diganti dengan membayar diyat kepada keluarga korban atau wali. 
Wali adalah orang yang berhak menuntut pembalasan, yaitu ahli waris dari korban. Wali inilah yang berhak menuntut dijatuhkannya pidana terhadap pelaku, bukan penguasa (pemerintah). Tugas pemerintah hanyalah menangkap si pembunuh. Oleh karena itu keputusan sepenuhnya diserahkan kepada wali korban. Menurut Imam Malik orang yang berhak menuntut qishas atau memaafkannya adalah ashabah bi nafsih, yaitu orang yang paling dekat dengan korban. Sedangkan menurut Imam Abu Hanifah, Imam Syafi'i dan Imam Ahmad orang yang paling berhak adalah seluruh ahli waris lakilaki maupun perempuan. Mengenai besarnya diyat, dijelaskan dalam Hadist Rasulullah SAW, yang artinya : "Barangsiapa yang membunuh (orang tak bersalah) secara sengaja (dan terencana), maka urusannya kepada pihak keluarga si terbunuh. Jika mereka mau, menuntut hukum balas membunuh; dan jika mau, mereka menuntut diyat, yaitu (membayar) tiga puluh hiqqah (onta betina berusia tiga tahun yang masuk tahun keempat) dan tiga puluh jadza'ah (onta yang masuk tahun kelima) serta empat puluh khalifah (onta yang sedang bunting) dan, apa saja yang mereka tuntut kepada si pembunuh sebagai imbalan perdamaian, maka ia (imbalan itu) untuk mereka, dan yang demikian itu untuk penekanan pada diat". Besarnya diyat yang harus dibayarkan adalah sebanyak 100 ekor onta, dengan spesifikasi sebagai berikut:

a. Tiga puluh hiqqah (onta betina berusia tiga tahun yang masuk tahun keempat)

b. Tiga puluh jadza'ah (onta yang masuk tahun kelima atau sudah dewasa)

c. Empat puluh khalifah (onta yang sedang bunting).

Pada diyat pembunuhan yang disengaja adalah diyat mughallazhah (diyat berat), yaitu diyat yang diperberat, diyat ini pembayarannya hanya diambil dari harta pelaku saja dan harus dibayar tunai. Pembayaran diyat hendaknya diminta dengan baik, misalnya dengan dengan tidak mendesak yang membunuh apabila memang belum mampu untuk membayarnya, dan yang membunuh hendaknya juga membayarnya dengan baik, misalnya tidak menunda-nunda pembayarannya jika memang sudah mampu untuk 
membayarnya. Selain itu juga tidak boleh menuntut pembayaran diyat yang melebihi batas yang besarnya sudah ditentukan seperti pada tersebut diatas.

Abu Hanifah berpendapat bahwa pembunuhan yang disengaja jika dimaafkan oleh keluarganya, tidak dituntut pembayaran diyat yang telah ditentukan besarnya melainkan tergantung dari persetujuan dari keluarga korban dengan pelaku, dan apa yang telah disepakati oleh kedua belah pihak harus dibayar tunai dari harta si pembunuh itu sendiri. Pendapat Abu Hanifah ini didasarkan atas tidak disebutkannya dengan jelas berapa besar penggantian diyat dalam Al-Quran. ${ }^{10}$ Namun apabila keluarga korban memberikan pemaafan secara cuma-cuma, yaitu pemaafan secara mutlak kepada pelaku dari keluarga korban tanpa menuntut hukuman apapun maka pelaku pembunuhan dapat terbebas dari hukuman qishas maupun diyat. Para ulama sepakat tentang kebolehan pemaafan secara cuma-cuma ini. Pada hukum pidana yang diatur dalam KUHP, tidak dikenal adanya pemaafan secara cuma-cuma dari keluarga korban apabila telah terjadi tindak pidana pembunuhan yang disengaja.

Pada hukum Islam, pemaafan cuma-cuma ini dapat memungkinkan pelaku terbebas dari hukuman qishas dan diyat, namun dalam hukum pidana Indonesia pemaafan dari keluarga korban terhadap pelaku pembunuhan tidak dapat mempengaruhi ancaman pidananya karena keputusannya sepenuhnya ditangan Hakim yang memeriksa dan mengadili berdasarkan bukti-bukti yang telah ada. Sanksi pidana pembunuhan dalam KUHP tidak terdapat hukuman yang mengharuskan memberikan ganti rugi kepada keluarga korban, misalnya membayar diyat seperti pada hukum Islam. Karena dalam hukum pidana yang diatur dalam KUHP, hukum pidana merupakan mutlak hukum publik dimana penyelesaiannya sepenuhnya menjadi hak negara. Namun bila kita perhatikan, sebenarnya pihak yang paling dirugikan apabila terjadi tindak pidana pembunuhan adalah keluarga korban, sebab sudah barang tentu keluarga korban akan merasa kehilangan salah satu anggota keluarganya dan mungkin akan kehilangan sumber

${ }^{10}$ Ahmad Azhar Basyir. 2006. Ikhtisar Fikih Jinayat (Hukum Pidana Islam). Yogyakarta : Universitas Islam Indonesia Press, hal 21 
penghasilannya apabila korbannya merupakan tulang punggung keluarga yang bekerja untuk mencari nafkah bagi keluarganya.

Oleh karena itu sanksi pidana penjara yang diatur dalam KUHP mungkin hanya akan memberikan keadilan dari aspek batiniah dari keluarga korban karena pelaku sudah mendapatkan sanksi pidana yang setimpal berupa dipidana penjara selama waktu tertentu, namun dari aspek materiil keluarga korban tidak mendapatkan balasan atau ganti rugi apapun dari pelaku. Sehingga dalam hukum Islam tujuan dari pembayaran diyat kepada keluarga korban ini adalah sebagai ganti rugi materiil dari pelaku karena telah membunuh salah satu anggota keluarga korban yang menjadi sumber pencari penghasilan bagi keluargnya. Pada pembunuhan yang berencana, KUHP memberikan sanksi pidana yang paling berat diantara bentuk pembunuhan yang lainnya, yaitu berupa pidana mati atau penjara seumur hidup atau selama waktu tertentu paling lama dua puluh tahun sebagaimana diatur pada 340 KUHP.

Faktor adanya perencanaan inilah yang menjadi dasar beratnya hukuman ini dibandingkan dengan pembunuhan yang lain. Terdapat 3(tiga) syarat/unsur dari adanya rencana terlebih dahulu ini, yaitu: ${ }^{11}$

a) Memutuskan kehendak dalam suasana batin yang tenang Maksudnya ialah pada saat melaksanakan kehendak untuk membunuh dilakukan dalam suasana batin yang tenang. Suasana batin yang tenang adalah suasana yang tidak tergesa-gesa atau tiba-tiba, tidak dalam keadaan terpaksa dan emosi yang tinggi. Sebelum memutus kehendak untuk membunuh, sudah dipertimbangkan dan dipikirkan mengenai untung dan ruginya, resiko, cara yang digunakan, alat yang digunakan dan sebagainya.

b) Adanya waktu yang cukup lama sejak timbulnya kehendak sampai dengan pelaksanaan kehendak Waktu yang cukup lama atau tenggang waktu ini adalah relatif, artinya tidak diukur dari lamanya waktu tertentu, melainkan tergantung pada keadaan atau kejadian

${ }^{11}$ Adami Chazawi. 2001. Kejahatan Terhadap Tubuh \& Nyawa. Jakarta : Raja Grafindo Persada. hal 82. 
konkret yang berlaku. Dalam tenggang waktu ini terdapat hubungan antara pengambilan putusan kehendak dengan pelaksanaan kehendak. Artinya bahwa pelaku masih mungkin untuk menarik kehendaknya untuk membunuh, dan ada waktu untuk memikirkan cara dan alat apa yang akan digunakannya.

c) Pelaksanaan kehendak (perbuatan) dalam suasana batin yang tenang Maksudnya ialah pada saat melaksanakan pembunuhan tidak dalam suasana yang tergesa-gesa, rasa takut, ancaman, emosi yang berlebihan, dan sebagainya. Ketiga unsur/syarat mengenai perencanaan diatas, bersifat kumulatif, artinya apabila salah satu dari unsur/syarat tersebut tidak terpenuhi, maka sudah tidak dapat lagi disebut sebagai perencanaan.

\section{Pembunuhan tidak Disengaja}

Pembunuhan yang tidak disengaja adalah pembunuhan yang terjadi karena pelaku tidak menghendaki akibat dari perbuatannya. Mengenai tindak pidana pembunuhan yang tidak disengaja ini, diatur dalam Pasal 359 KUHP. Terhadap setiap orang karena kealpaannya menyebabkan matinya orang lain, menurut KUHP diancam dengan pidana penjara paling lama lima tahun atau kurungan paling lama satu tahun.

Bentuk dari kealpaan ini dapat berupa perbuatan yang pasif maupun aktif. Contoh perbuatan yang pasif misalnya penjaga palang pintu kereta api karena tertidur pada waktu ada kereta yang melintas dia tidak menutup palang pintu sehingga mengakibatkan tertabaraknya mobil yang sedang melintas. Bentuk kealpaan penjaga palang pintu ini berupa perbuatan yang pasif karena tidak melakukan apa-apa. Sedangkan contoh perbuatan yang aktif misalnya seseorang yang sedang menebang pohon ternyata menimpa orang lain sehingga matinya orang itu karena tertimpa pohon. Bentuk kealpaan dari penebang pohon ini berupa perbuatan yang aktif.

Hukum Islam mendefinisikan pembunuhan yang tidak disengaja adalah seorang mukalaf yang melakukan pembunuhan karena adanya kesalahan. Pembunuhan karena kesalahan diatur dalam Al Quran Surat An-Nisa' ayat 92, yang artinya : “Dan tidak layak bagi seorang mukmin membunuh seorang mukmin (yang lain), kecuali karena tersalah (tidak sengaja), dan barangsiapa membunuh seorang mukmin 
karena tersalah (hendaklah) ia memerdekakan seorang hamba sahaya yang beriman serta membayar diat yang diserahkan kepada keluarganya (si terbunuh itu), kecuali jika mereka (keluarga terbunuh) bersedekah. Jika ia (si terbunuh) dari kaum yang memusuhimu, padahal ia mukmin, maka (hendaklah si pembunuh) memerdekakan hamba sahaya yang mukmin. Dan jika ia (si terbunuh) dari kaum (kafir) yang ada perjanjian (damai) antara mereka dengan kamu, Maka (hendaklah si pembunuh) membayar diat yang diserahkan kepada keluarganya (si terbunuh) serta memerdekakan hamba sahaya yang beriman. Barangsiapa yang tidak memperolehnya, Maka hendaklah ia (si pembunuh) berpuasa dua bulan berturutturut untuk penerimaan Taubat dari pada Allah. dan adalah Allah Maha mengetahui lagi Maha Bijaksana”. Dalam ayat diatas terdapat ketentuan sebagai berikut:

a. Seorang mukmin yang tidak sengaja membunuh mukmin lainnya, maka diwajibkan membayar kifarat berupa memerdekakan seorang hamba sahaya mukmin dan membayar diyat yang diserahkan kepada keluarga korban.

b. Seorang mukmin yang membunuh mukmin lainnya dari kaum yang memusuhinya karena tidak sengaja, hanya diwajibkan membayar kifarat berupa memerdekakan seorang hamba sahaya mukmin.

c. Seorang mukmin yang tidak sengaja membunuh orang kafir yang ada perjanjian damai, diwajibkan membayar kifarat berupa memerdekakan seorang hamba sahaya mukmin dan membayar diyat yang diserahkan kepada keluarga korban.

d. Jika tidak mungkin memerdekakan budak, maka dapat diganti dengan cara berpuasa selama dua bulan berturut-turut. Pada pembunuhan yang tidak disengaja, besarnya diyat yang harus dibayarkan kepada keluarga korban jumlahnya sama dengan pembunuhan yang disengaja, yaitu berupa 100 ekor onta.

Tetapi jenis/klasifikasi ontanya berbeda. Abdullah Ibnu Mas'ud r.a telah menceritakan Hadist berikut, bahwa Rasulullah SAW pernah bersabda, yang artinya: "Diyat pembunuhan karena keliru (tersalah) ialah dua puluh ekor onta hiqqah, dua puluh ekor onta jadza'ah, dua puluh ekor onta bintu makhadh, dua puluh ekor onta bintu labun, dua puluh ekor onta bani makhadh yang betina" (H.R. Ash-habus Sunan). 
Pada pembunuhan tidak sengaja, diyatnya ialah mukhafafah (diyat ringan), diyat ini pembayarannya tidak hanya dibebankan kepada korban saja, melainkan juga bisa kepada keluarganya, selain itu pembayarannya juga dapat diangsur selama tiga tahun. Membebankan diyat mukhafafah kepada keluarga pelaku dengan pertimbangan bahwa pelaku sedang tertimpa musibah karena ketidaksengajaanya menyebabkan matinya orang lain sehingga diwajibkan membayar diyat maupun kifarat, oleh sebab itu keluarganya sepantasnya menolong saudaranya yang sedang mengalami musibah. Namun apabila pelaku maupun keluarganya benar benar tidak mampu untuk membayarnya, maka yang membayar diyat adalah Negara yang diambil dari baitulmal (kas Negara). Hal ini didasarkan pada Hadist Nabi SAW yang mengajarkan, yang artinya"Aku adalah wali bagi orang yang tidak mempunyai wali sama sekali".

Pembunuhan yang tidak disengaja, menurut hukum Islam dan KUHP sanksi pidananya lebih ringan daripada pembunuhan yang disengaja. KUHP hanya memberikan sanksi pidana penjara paling lama lima tahun atau bahkan mungkin hanya dipidana kurungan paling lama satu tahun. Hal ini tentu jauh lebih ringan bila dibandingkan dengan pembunuhan yang disengaja yang diatur pada Pasal 338 KUHP dimana ancaman pidananya bisa lima belas tahun penjara. Sedangkan menurut hukum Islam, sanksi pidana pembunuhan yang tidak disengaja juga lebih ringan daripada pembunuhan yang disengaja. Pada pembunuhan yang tidak disengaja tidak diancam dengan hukuman qishas.

Apabila ada dinding yang roboh menimpa orang lain hingga mati, menurut Imam Hanafi orang yang memiliki tembok tersebut dapat dimintai pertanggung-jawaban apabila sebenarnya ia mampu untuk memperbaikinya, namun apabila ia tidak mampu maka pemilik tembok tidak dapat dimintai pertanggung-jawaban. Apabila seseorang menggali sumur atau lubang, lalu ada orang lain yang terperosok kedalamnya hingga mati, Imam Malik berpendapat bahwa apabila menggalinya di suatu tempat yang biasa untuk membuat sumur atau lubang, maka si penggali tidak dapat dituntut pertanggung-jawaban., tetapi apabila penggaliannya melewati batas penggalian, si penggali dapat dituntut pertanggungjawaban. ${ }^{12}$ Pada kedua kasus

\footnotetext{
12 Sayyid Sabiq. 2004. Fikih Sunnah. Bandung : PT. Alma'arif. hal 149
} 
diatas menurut hukum pidana orang yang memiliki dinding dan yang menggali sumur/lubang dapat dituntut pertanggung-jawaban apabila memang terbukti ada kelalaian atau kealpaan dari pemilik dinding atau penggali sumur/lubang.

Apabila pemilik dinding sudah mengetahui bahwa dindingnya akan roboh namun ia tetap membiarkannya, lalu ada orang lain yang tertimpa hingga mati, maka ia dapat dituntut pertanggung-jawaban dan terhadap penggali sumur/lubang yang menggali ditempat yang tidak biasanya atau yang sering dilewati orang, kemudian ada orang lain yang terperosok hingga mati karena tidak ada tanda peringatan atau menutup lubangnya maka ia dapat dituntut pertanggungjawaban karena kealpaan/kelalaiannya menyebabkan matinya orang lain, pembunuhan yang tidak disengaja yang merupakan akibat ketidak hati-hatian selain dikenai hukuman diyat, juga dapat digabungkan dengan hukuman $t a^{\prime} z i r$, karena $t a^{\prime} z i r$ itu bersifat perorangan dan bukan merupakan hukum yang bersifat umum."13

Sedangkan dalam KUHP, pelaku pembunuhan yang tidak disengaja selain dapat dikenai sanksi pidana penjara dapat juga dikenai sanksi pidana kurungan. Pidana kurungan sifatnya lebih ringan daripada pidana penjara, misalnya pidana kurungan ini bisa diganti dengan membayar denda sehingga tidak perlu melaksanakan hukuman kurungan bila sudah membayar denda. Sebagai contoh dari sanksi pidana yang dijatuhkan hakim terhadap pelaku tindak pidana kejahatan terhadap nyawa, diambil dari putusan Pengadilan Nomor: 88/ Pid.B/ 2008/ PN. Skg. Seorang supir truk bernama Sama, umur 35 tahun, telah menabrak seorang pengendara motor bernama $\mathrm{H}$ darman hingga tewas. Berdasarkan keterangan saksi dan bukti yang ada, maka terdakwa telah terbukti secara sah dan meyakinkan bersalah melakukan tindak pidana karena "kesalahannya menyebabkan matinya orang lain" sebagaimana yang diatur dalam Pasal 359 KUHP. Hakim menjatuhkan hukuman berupa pidana penjara selama 6 (enam) bulan. Meskipun dalam KUHP terhadap pelaku pembunuhan karena kesalahan atau kealpaan diancam dengan pidana penjara paling lama lima tahun atau kurungan paling lama satu tahun. Hakim memberikan keringanan hukuman ini dengan pertimbangan bahwa terdakwa mengakui terus terang akan perbuatannya dan berjanji tidak akan mengulangi lagi, terdakwa

\footnotetext{
${ }^{13}$ H.A. Djazuli. 2000. Fiqh Jinayah. Jakarta : Raja Grafindo Persada. hal 176
} 
menyesali atas perbuatannya, dan terdakwa juga belum pernah dipidana sebelumnya. Tujuan dari pemberian sanksi pidana pembunuhan yang tidak disengaja ini adalah supaya orang lebih berhati-hati dalam melakukan perbuatannya agar tidak merugikan orang lain lebih-lebih sampai berakibat kematian. Sebab agama dan negara sangat menghormati hak hidup manusia, sehingga tidak mungkin akan membiarkan hilangnya nyawa yang disebabkan karena kelalaian orang lain tanpa dikenai sanksi.

\section{KESIMPULAN DAN SARAN}

Hukum pidana Indonesia maupun hukum pidana Islam menguraikan unsur kesengajaan adalah berupa perbuatan yang dikehendaki pelakunya akan menimbulkan suatu akibat tertentu. Dalam hal tindak pidana pembunuhan yang disengaja, akibat yang dikehendaki oleh pelaku adalah meninggalnya orang lain. Sedangkan pada pembunuhan yang tidak disengaja pelaku tidakmenghendaki akibat yang akan terjadi. Oleh sebab itu dalam KUHP maupun hukum Islam sanksi pidana pembunuhan yang disengaja akan lebih berat daripada yang tidak disengaja. Sanksi pidana pembunuhan yang diatur dalam KUHP dapat berupa pidana mati, pidana penjara, pidana kurungan dan pidana tambahan. Sedangkan dalam hukum pidana Islam sanksi pidana pembunuhan dapat berupa hukuman qishash, hukuman diyat, kifarat, dan hukuman ta'zir. Hukum pidana Indonesia merupakan mutlak hukum publik (hukum Negara), yaitu hukum yang mengatur hubungan antara orang/perseorangan (warga negara) dengan Negara. Sehingga yang berhak untuk menentukan hukumannya adalah Negara tanpa ada campur tangan dari orang lain.

Sedangkan dalam hukum pidana Islam tidak membedakan antara hukum privat dan hukum publik. Sehingga memungkinkan adanya campur tangan dari orang/perseorangan maupun dari pemerintah (penguasa) dalam menentukan hukumannya. Hukum pidana Indonesia dalam hal terjadi tindak pidana pembunuhan, proses hukumnya secara mutlak menjadi hak Negara untuk menentukan hukuman apa yang akan dijatuhkan kepada pelaku, Negara yang akan menentukan berat-ringannya hukuman berdasarkan bukti-bukti yang ada. Sedangkan dalam hukum pidana Islam, apabila terjadi tindak pidana pembunuhan yang berhak menentukan sanksi pidananya adalah pihak keluarga atau ahli waris 
dari korban, apakah pelaku akan dijatuhi hukuman qishas, atau dimaafkan dengan membayar diyat atau dimaafkan secara cuma-cuma. Hukum pidana Islam mengenal adanya pemaafan secara cuma-cuma dari keluarga korban kepada pelaku atas pembunuhan yang telah dilakukannya. Pemaafan secara cuma-cuma ini memungkinkan pelaku pembunuhan tidak akan mendapatkan sanksi pidana apapun. Sedangkan dalam hukum pidana Indonesia meskipun pelaku tindak pidana pembunuhan sudah mendapatkan pemaafan dari keluarga korban, proses hukumnya masih tetap berjalan karena yang menentukan hukumannya adalah Negara. Sanksi pidana pembunuhan dalam hukum Islam selain diberikan di dunia, pelaku juga akan mendapatkan hukuman di akhirat berupa dimasukkan kedalam neraka Jahannam dan mendapatkan azab yang pedih dari Allah apabila pelaku tidak bertobat kepada Allah atas perbuatan yang telah dilakukannya.

Atikel ini mengemukakan saran bahwa, manusia merupakan mahluk yang paling dimuliakan Allah. Hak yang paling utama dan dijamin oleh agama maupun oleh Negara adalah hak hidup. Hak tesebut merupakan hak milik manusia secara mutlak tanpa mempertimbangkan agama, bangsa dan kedudukan dalam masyarakat. Oleh sebab itu seharusnya hak hidup tersebut harus dijaga dan dilindungi. Pembunuhan itu menghancurkan tata nilai hidup yang telah dibangun oleh kehendak Allah SWT dan merampas hak hidup orang yang menjadi korban, sekaligus dapat mengakibatkan permusuhan dengan keluargakorban dan juga mungkin dapat mengganggu kesejahteraan dan kemakmuran kehidupan keluarga korban apabila korban merupakan tulang punggung keluarga. Sehingga sepantasnya terhadap pelaku pembunuhan, khususnya yang disengaja dan terencana mendapatkan hukuman yang seberat-beratnya mengingat kejahatan yang telah dilakukannya.

Apabila terjadi tindak pidana pembunuhan hendaknya pelaku segera meminta maaf kepada keluarga korban dan keluarga korban hendaknya juga dengan lapang dada menerima permintan maaf tersebut dengan baik. Saling memaafkan merupakan perbuatan yang paling mulia disisi Allah dan akan lebih mendekatkan kepada ketakwaan. Kepada aparat penegak hukum, berikanlah keadilan yang seadil-adilnya baik kepada pelaku kejahatan maupun kepada keluarga korban pada waktu memberikan hukuman. Supaya dapat membuat jera terhadap pelakunya agar tidak 
mengulanginya lagi dan juga sebagai peringatan terhadap orang lain supaya tidak melakukan tindak pidana pembunuhan.

\section{REFERENSI}

Abuddin Nata. 2001. Sejarah Perkembangan dan Pendidikan Islam di Indonesia. Jakarta : Gramedia.

Adami Chazawi. 2001. Kejahatan Terhadap Tubuh \& Nyawa. Jakarta : Raja Grafindo Persada.

2005. Pelajaran Hukum Pidana I. Jakarta. Raja Grafindo Persada.

Ahmad Azhar Basyir. 2006. Ikhtisar Fikih Jinayat (Hukum Pidana Islam). Yogyakarta : Universitas Islam Indonesia Press.

Ahmad Hanafi. 1967. Asas-asas Hukum Pidana Islam. Jakarta : Bulan Bintang.

Andi Hamzah. 1986. Sistem Pidana dan Pemidanaan Indonesia dari Retribusi ke Reformasi. Jakarta : Pradnya Paramita.

Bambang Poernomo. 2000. Asas-asas Hukum Pidana. Yogyakarta : Ghalia Indonesia.

C.S.T.Kansil. 1989. Pengantar Ilmu Hukum dan Tata Hukum Indonesia. Jakarta : Balai Pustaka.

H.A. Djazuli. 2000. Fiqh Jinayah. Jakarta : Raja Grafindo Persada.

Ilham Bisri. 2004. Sistem Hukum Indonesia. Prinsip-Prinsip dan Implementasi Hukum di Indonesia. Jakarta : Raja Grafindo Persada.

Lexy J. Moelong. 2002. Metodologi Penelitian Kualitatif. Bandung: Remaja Rosdakarya.

Johnny Ibrahim. 2006. Teori \& Metodelogi Penelitian Hukum Normatif. Malang : Bayumedia.

Leden Marpaung. 2005. Asas, Teori, Praktek Hukum Pidana. Jakarta : Sinar Grafika.

Marsum. 2008. Jinayat (Hukum Pidana Islam). Yogyakarta : Universitas Islam Indonesia Press. 
Moeljatno. 2000. Asas-asas Hukum Pidana. Yogyakarta : Universitas Gadjah Mada Press.

Mohd. Idris. Ramulyo. 2007. Asas-asas Hukum Islam. Jakarta : Sinar grafika.

Oemar Seno Adji. 2004. Hukum-Hakim Pidana. Jakarta : Erlangga.

Romli Atmasasmita. 2000. Perbandingan Hukum Pidana. Bandung : CV. Mandar Maju

Sayyid Sabiq. 2004. Fikih Sunnah. Bandung : PT. Alma'arif.

Soerjono Soekanto. 2006. Pengantar Penelitian Hukum. Jakarta: Universitas Indonesia Press.

Sudarto. 2000. Hukum Pidana I. Semarang : Yayasan Sudarto. 